G81

転移性肺腫韵手術症例の検討

北九州市立医療センター呼吸器外科

産業医科大学第二外科 ${ }^{*}$

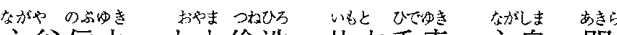
永谷信之、小山倫浩、井本秀幸、永島 明

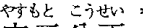

安元公正

【目的および対象】1992年から1995年迄に経験 した転移性肺腫瘍手術症例 40 例を対象に、病態、 予後を中心に検討したので報告する。

【結果】40例の平均年令は62歳であり、男性は 14例、女性は26例であった。原発臓器は、大腸 14 例、乳腺 8 例、甲状腺 4 例、肺 3 例、子宮 2 例、肝 2 例、 肉腫 3 例、顎下腺、胆囊、胃、睪丸各 1 例であった。 肺転移巣の完全切除不能例( 乳癌 3 例、大腸癌 3 例、 甲状腺癌 1 例、肉腫各 1 例)を除いた 32 例の転移性肺 腫瘍切除後 3 年生存率は $87 \%$ であった。大腸癌の肺 転移完全切除11例における、転移性肺腄瘍切除後3 年生存率は $80 \%$ あった。また、この11例のうち 単発と多発肺転移症例はそれぞれ9例と2例であり、 現時点で多発肺転移症例には2例ともに再発を認め、 単発例では5例に再発を認めた。この再発形式は肺 局所再発が 2 例、肺転移 3 例、脳及び肝転移を各 1 例 認めた。乳癌では肺および骨転移各 1 例を認めるも のの完全切除不能例を除く5例の転移性肺腫瘍切除 後 3 年生存率は $100 \%$ であった。

\section{9 大腸癌の多発肺転移に対する手術適応}

国立病院九州がんセンター呼吸器外科 矢野篤次郎, 横山秀樹, 福山康朗, 高井英二, 田中優一，一瀨幸人

【目的】われわれは第 9 回本学会総会にて, 大腸癌肺 転移切除後の予後因子として, 転移個数が唯一重要で あることを報告した。今回は多発転移例の再発形式を 明らかにし，手術適応について考察した。【対象】 1981年より1993年までに, 当科で完全切除された大 腸癌肺転移症例36例を対象とした。転移個数の内訳 は単発17例，2個8例，4個1例，5個1例，6個2例，7個 5例，8個1例，10個1例であった。【結果及び考察】 転移個数別の術後 5 年無再発生存率は, 単発例 $(n=$ 17) 65\%，2個例 $(n=8) 38 \%$ ，4個以上例 $(n=11) 0 \%$ で つた。4個以上の多発転移例11例の再発形式は，原発 局所再発(骨盤内)6例, 肝転移2例, 肺転移2例, 脳転 移1例で, 結果的には半数以上の症例が局所コント ロール不完全例であった。2個例も同様に, 再発例5 例中3例が局所再発であった。一方, 単発例では再発 例7例のうち局所再発は1例のみであった。再発例の みの無再発期間中央值を見ても, 単発例 $(n=7) 18$ 力月 に対し，4個以上多発例 $(n=11)$ 4力月と再発形式の違 いが反映されていた。以上のことょり, 多発肺転移例 の半数以上に局所再発が潜んでおり, 肺転移手術適応 決定時には，十分な骨盤内精查が必要と考えられる。
G 82 無病期間が 10 年以上であった転移性肺腫瘍 切除例 6 例の検討

国立療美所西群墨病院外科 ${ }^{1}$, 群馬大学第 2 外科 ${ }^{2}$

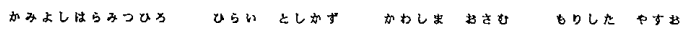
上吉原光宏 ${ }^{1}$, 平井利和 ${ }^{1}$, 川岛 修 ${ }^{1}$, 森下靖雄 ${ }^{2}$

【目的】原発巣治㙩から肺転移発見までの期間,即 与無病期間(DFI)が 10 年以上の転移性肺腫演切除 瘤例において，その臨床的特徵について検討した。

【対象】1980年12月～1995年12月までに当科で 释験した転移性肺腫場切除例 32例中,DFIが 10年以 上の症例は6例(127〜235个月,平均153.3个月)であ った。性別は男 3 例,女 3 例, 年龄は $55 \sim 72$ 藏 (平均 63.2 歳)で西った。原発策は乳腺 2 例(腺癌, 粘液源), 皮膚 (平滑筋肉腫), 粘腸 (腺癌), 甲状腺(乳頭癌), 膀胱 (移行上皮癌)が各 1 例であった。【結果】肺転移巣は 単発が4例,多発が2例で,多発例はいづれも一側性 であり転移個数は2個であった。術式は全例に葉切 が行われた.4例にリンパ節郭清が行われ,1例(移行 上皮癌)に転移がみられた。術後化学燎法は 4 例に行 われた，検討可能な 4 例の腫懪倍加日数は80 814 日(平均337.2日)であった。予後は結晹癌, 乳演の各 1例が肺再発でそれぞれ16,43个月で死亡した.残り 4例は4〜66ケ月の間生存中である.【結諭】DFIが 長期の症例でも肺転移切除後比較的早期に肺再発 で死亡する症例がみられた.DFIにかかわらず敳重 な経過観察が必要と思われた。

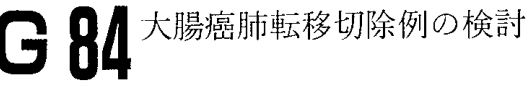

厚生連高岡病院呼吸器外科

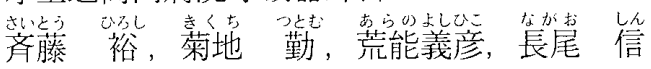

大腸癌肺転移切除例の手術成績からその手術適応を 再検討した。

【対象】過去 8 年間に切除した大腸癌肺転移 19 例を対 象とした。適応は, 肺以外に病巣のない症例で, 肺内 転移個数は画像診断上 4 個までとした。平均年齢は 63. 7 歳，男女比 $16: 3$ であった。

【術式】単発例は葉切除兼緃隔郭清, 多発例は部分切除 を原則とした。

【結果】平均切除個数は $3.1 \pm 4.3$ 個で, 単発例 8 例, 一 側多発 5 例, 雨側例 6 例であった。全症例の 5 年生存率 は39\%であった。転移個数, 無病期間, 転移部位, 腫 場最大径でそれぞれ2 群に分けた 5 生率は, 個数 1 2 個群 $55 \%, 3$ 個以上群 $0 \%(\mathrm{p}<0.01)$, 無病期間 2 年 未満群 $67 \%, 2$ 年以上群 $22 \%$ (NS), 一側例 $41 \%$, 両 側例 $31 \%$ (NS), 最大径 $3 \mathrm{~cm}$ 未満群 $53 \%$, 3cm 以上 群 $27 \%$ (4 年生存率) (NS) であった。死亡7 例の死 因は脳転移 3 例, 肺内転移再発 2 例, 癌性心膜炎 1 例, 腹腔内再発 1 例であった。

【結語】調べた因子の中では転移個数のみが予後を規 定する最も有力な因子であった。3個以上の症例につ いては適応を慎重にする必要がある。 